\title{
Low Socioeconomic School Composition as an Indicator of Low Educational Attainment: Evidence from Slovakia
}

\section{Tomáš Lintner}

\begin{abstract}
This study is first of its kind in Slovakia using large-scale nation-wide government agency data documenting students' destinations after leaving elementary schools with high representation of socially disadvantaged children. Secondary aggregate data obtained from elementary schools and the Ministry of Education covering approximately a quarter of all Slovak socially disadvantaged children in Years 1-9 were compiled into a new dataset. A cross-sectional analysis revealed that, compared to the country average, students leaving elementary schools with high ratios of socially disadvantaged children are more likely to stop attending schools and less likely to continue at academic strand schools. Overall, I found very high inter-school variations in students' destinations implying that some schools are more successful than others in alleviating the negative effects of low socioeconomic school composition on educational attainment. Small number of low socioeconomic composition schools showed similar or better record of students' destinations than the Slovak average.
\end{abstract}

Key words: school composition; social disadvantage; socially disadvantaged students; educational attainment; attainment gap; educational inequality. 


\title{
Nízke socioekonomické zloženie školy ako indikátor nízkeho dosiahnutého vzdelania: Prípad Slovensko
}

\begin{abstract}
Abstrakt
Táto štúdia je prvá svojho typu na Slovensku, ktorá za využitia verejne prístupných dát z celej krajiny mapuje cesty absolventov základných škôl s vysokým zastúpením sociálne znevýhodnených detí. Sekundárne agregované dáta zozbierané zo slovenských základných škôl a Ministerstva školstva pokrývajúce približne štvrtinu všetkých sociálne znevýhodnených študentov na základých školách boli spracované do nového datasetu. Prierezová analýza ukázala, že v porovnaní so slovenským priemerom, žiaci končiaci základné školy s vysokým zastúpením sociálne znevýhodnených detí s väčšou pravdepodobnostou nepokračujú v d’alšom vzdelávaní a s menšou pravdepodobnostou pokračujú na gymnáziách. Základné školy naprieč Slovenskom vykazujú vel'kú mieru variability v študijných dráhach absolventov, čo naznačuje, že niektoré školy sú úspešnejšie v zmierňovaní dopadov sociálneho znevýhodnenia na dosiahnuté vzdelanie než iné. Malé množstvo základných škôl s vel'kým zastúpením sociálne znevýhodnených žiakov vykazuje porovnatel'né či dokonca lepšie výsledky v umiestňovaní absolventov na d’alšie štúdium v porovnaní so slovenským priemerom.
\end{abstract}

Klúčové slová: socioekonomické zloženie školy; sociálne znevýhodnenie; sociálne znevýhodnení žiaci; najvyššie dosiahnuté vzdelanie; nerovnost' vo vzdelávaní.

DOI: $10.5507 /$ epd.2021.010

\section{Introduction}

Student's socioeconomic status has been proved to influence their educational attainment, with low socioeconomic status linked to lower educational attainment (e.g. Hair et al., 2015; Paterson, 1991; Eagle, 1989). Furthermore, school composition has been found to have influence on educational achievement additional to the effect of the social background of the individual students (Cascella, 2020), with similar findings provided by Willms (2010) using PISA 2006 data. As in other countries, educational attainment in Slovakia plays an important part in career success and income later in life. On average, adults in Slovakia attaining at least full upper-secondary education have average to above-average income and relatively low unemployment rate at $10.9 \%$ compared to those without full upper-secondary education with below-average income (Čitáryová \& Chrenko, 2011) and high unemployment rate at 44.6\% (Friedman et al., 2009). On many occasions, Slovak authorities have declared an intention to alleviate 
the effects of low socioeconomic status on educational attainment and this aim has been present in draft legislation programmes of all Slovak governments over the last twenty-five years (Government Office of the Slovak Republic, 2020).

Aiming to identify the present-day influence of low socioeconomic school composition on educational attainment in Slovakia on a nation-wide scope, I employ a quantitative secondary data analysis utilizing data collected by elementary schools ${ }^{1}$ and the Ministry of Education published in annual reports. In this study, a low socioeconomic school composition is operationalized as over-representation of socially disadvantaged children among attending students. On the other hand, educational attainment is operationalized as students' educational destinations after leaving elementary school. Therefore, this study aims to address the following question: How do students' educational destinations after leaving elementary school in Slovakia differ in relation to socioeconomic composition of the school?

\section{Social disadvantage in Slovakia}

In Slovakia, the term of social disadvantage has been used non-uniformly with no single operational definition - the term has been used to denote several conditions ranging from poverty to social exclusion (Bakošová, 2016; Kovalčíková \& Džuka, 2014). Moreover, social disadvantage in Slovakia has been stereotypically linked to Romani people and while Romani people have historically been most susceptible social group to social exclusion, not all Romani children are socially disadvantaged as not all socially disadvantaged children are Romani (Farkašová \& Zimmermann, 2014). Only recently, the Ministry of Education has specified social disadvantage among children as a combination of indicators comprising family poverty, parental unemployment, parental low educational attainment, unsuitable living conditions, minority mother tongue, and social exclusion (Ministry of Education, 2013). This specification is used by independent third-party counselling centres to identify socially disadvantaged children coming to schools. Correspondingly, this specification is adopted by this study since data from the Ministry of Education are used to identify schools with high representation of socially disadvantaged children. Social disadvantage in the context of contemporary Slovak system of education therefore encompasses a wide range of conditions, which are, due to the nature of primary data collection (by counsellors at the centres), impossible to be analysed independently. However, these conditions co-occur and socially disadvantaged children in Slovakia usually suffer from several conditions outlined by the Ministry at the same time (Rochovská and Rusnáková, 2018).

Elementary schools in Slovakia refer to schools providing first nine years of compulsory education covering grades 1 to 9 . 


\section{Method}

\subsection{Assessing school socioeconomic composition}

I made use of data collected by the Ministry of Education on a nation-wide level, specifically, the number of socially disadvantaged children at individual elementary schools. School socioeconomic composition was identified by calculating the percentages of socially disadvantaged children at the schools. Social disadvantage is a binary category, with students either being identified as not socially disadvantaged, or socially disadvantaged meeting the predefined criteria of the Ministry of Education outlined earlier.

\subsection{Sample}

I used a non-probability sampling method based on identifying all elementary schools meeting a pre-set criterion of being attended by at least 100 socially disadvantaged children in at least one of the three school years of 2015/2016, 2016/2017, or 2017/2018. Years in the span of the three school years were included to rule out an option of excluding schools, which are usually attended by high numbers of socially disadvantaged children, but which may have experienced temporary fluctuations in student numbers. To identify the schools meeting the inclusion criterion, I used the Annual Reports on Financial Contribution to Socially Disadvantaged Children from the Ministry of Education published online at https://www.minedu.sk/socialne-znevyhodnene-prostredieprispevok/, with 105 schools being included at this stage. Schools neither having the required data published on their website, or not responding to email requesting the data were further excluded $(n=33)$. Schools, which either had the required data published on their website, or which responded to my email with data for at least one required school year $(n=72)$ were included. The final sample contains $7.4 \%$ of all Slovak regular elementary school students in cohort numbers across the three years $(n=91621)$ and $26.5 \%$ of all Slovak socially disadvantaged students in cohort numbers across the three years $(n=39861)$.

\subsection{Data collection}

Once the schools were sampled, I collected data from their annual reports containing the number of leaving students by their educational destinations. These were, again, collected for a span of the three school years 2015/2016, 2016/2017, and 2017/2018 to rule out the effects of potential extreme fluctuations in student numbers by averaging the three-year student data and thus providing more balanced results. The data were collected at the end of 2018/2019 school year using school websites, or, in case the 
data were not published online, using request emails. All data concerning students are aggregates - they relate to the individual schools and not to the individual students.

The sample schools differed in categorization of student destinations where some provided specific information such as names, locations, types of schools, and study subjects, while some provided only a type of school. Therefore, I divided student educational destinations into three broad categories: continuing at academically focused high school; continuing at technically focused vocational school; not continuing at any school. The high school category contains all academic strand schools leading to upper secondary education including grammar schools, 4-year high schools, and 5 -year bilingual high-schools. The vocational school category contains all practical strand schools ranging from 2-year apprentice schools leading to practical certificate to 4-year full secondary schools leading to specialized upper secondary education. The last category includes all students who did not go to any type of school the year after finishing elementary school. Students in this category were often pregnant, started working, or did not come to school admission exams.

\subsection{Substituting missing data}

Some schools provided only partial data when either one or two school years were completely missing, or in some cases, the annual school reports did not contain educational destinations of all students. Missing data were substituted using person-mean substitution which means the missing values for variables were derived from the non-missing values of the same kind (Hawthorne \& Elliott, 2005). If some student destinations were unknown (14.34\%), their values were substituted with mean of non-missing student destinations from the same school and year. If data from one school year were missing $(25.00 \%)$, the values for all missing variables were substituted based on mean of nonmissing data of the same kind from the same school. In case data from two school years were missing, (9.72\%), the values for all missing variables were substituted based on the exact values from the non-missing year.

\subsection{Data analysis}

The sample schools were split into quartiles based on ratios of socially disadvantaged students with each quartile containing 18 of schools, roughly the same number of students in cohorts across the 3 years $(n=22500 \pm 2000)$, and roughly the same number of finishing students across the 3 years $(n=2200 \pm 700)$. I calculated sample mean and standard deviation (SD) of students' educational destinations by schools of the whole sample as well as of the individual quartiles and compared them to the Slovak average. To assess whether some low socioeconomic composition schools show record of student attainment comparable to the Slovak average, I identified number of schools 
in the sample with students in no school category lower than $5 \%\left(n_{1}\right)$ and schools with students in both no school category lower than $5 \%$ and high school category higher than $20 \%\left(n_{2}\right)$.

\section{Findings}

The findings are presented in Table 1. Compared to the Slovak average, students from the schools attended by at least 100 socially disadvantaged students enrol at high schools less often and more often do not continue at any school. On average, $10.77 \%$ of them continue at high schools and $21.57 \%$ do not continue anywhere, compared to the Slovak average of $31.71 \%$ of students continuing at high schools and only $2.42 \%$ not continuing at any school. When the sample schools are divided into the quartiles based on ratios of socially disadvantaged students with Q1 containing the lowestpercentage schools, high school enrolment gradually diminishes as one moves into the higher-percentage quartiles with lower socioeconomic composition. On the other hand, the percentage of students, who stop attending schools after leaving elementary school gradually rises with the lower socioeconomic composition quartiles, with Q4 being an exception with very high percentage of students continuing at vocational schools. Except for Q4, the enrolment at vocational schools remains similar to the Slovak average in all quartiles.

\section{Table 1}

Comparison of sample schools with Slovak average

\begin{tabular}{|c|c|c|c|c|c|c|}
\hline & Slovakia & sample & Q1 & Q2 & Q3 & Q4 \\
\hline soc. disadvantaged & & $44.14 \%$ & $24.13 \%$ & $39.49 \%$ & $48.68 \%$ & $64.26 \%$ \\
\hline high school average (SD) & $31.71 \%$ & $10.77 \%$ & $\begin{array}{l}16.90 \% \\
(10.87 \%)\end{array}$ & $\begin{array}{c}12.79 \% \\
(16.16 \%)\end{array}$ & $\begin{array}{l}7.56 \% \\
(8.21 \%)\end{array}$ & $\begin{array}{l}5.88 \% \\
(9.81 \%)\end{array}$ \\
\hline $\begin{array}{l}\text { vocational school average } \\
\text { (SD) }\end{array}$ & $65.86 \%$ & $67.83 \%$ & $\begin{array}{l}66.85 \% \\
(13.11 \%)\end{array}$ & $\begin{array}{l}67.84 \% \\
(17.93 \%)\end{array}$ & $\begin{array}{l}64.39 \% \\
(21.27 \%)\end{array}$ & $\begin{array}{l}72.24 \% \\
(23.14 \%)\end{array}$ \\
\hline no school average (SD) & $2.42 \%$ & $21.57 \%$ & $\begin{array}{l}16.24 \% \\
(16.54 \%)\end{array}$ & $\begin{array}{c}19.43 \% \\
(14.24 \%)\end{array}$ & $\begin{array}{l}28.06 \% \\
(21.41 \%)\end{array}$ & $\begin{array}{l}22.54 \% \\
(23.85 \%)\end{array}$ \\
\hline n1 & & 19 & 6 & 4 & 4 & 5 \\
\hline n2 & & 7 & 3 & 2 & 2 & 0 \\
\hline
\end{tabular}

I found significant differences in student destinations between schools in all quartiles, with standard deviations for schools in the quartiles often reaching $20 \%$ of the students for each type of educational destination. Furthermore, 19 of the 72 sample schools show low percentage of no school category students, with 7 schools also displaying 
high percentage of high school category students, suggesting that some schools with high representation of socially disadvantaged students are able to alleviate the negative effects of low socioeconomic composition on students' educational destinations. These schools, however, constitute a small minority.

\section{Discussion and conclusion}

Consistent with the previous research, the findings of this study suggest that low socioeconomic school composition is an indicator of potentially severing educational outcomes for the attending students. Lacking student-level data, it is impossible to separate the individual aspects of social disadvantage, as it is impossible to separate individual-level effects from class and school-level effects. Despite the presence of schools, which greatly differ in their students' educational destinations compared to the means of their respective quartiles, the Slovak system of education as a whole does not successfully alleviate the effects of social disadvantage on educational attainment.

The findings of this study yield several practical implications. Considering that some elementary schools with low socioeconomic composition are able to place their students to further education and prevent student dropouts, it would be beneficial to promote school networking and create a communication forum between these schools to share good practice and effective intervention strategies. It would also be beneficial to pursue qualitative research at elementary schools displaying significant anomalies in the outcomes of their students. Further research could identify effective practices in fighting low educational attainment. The data containing details from the individual schools in this study which may serve as an entry point for further research are available upon request.

\section{Acknowledgments}

This paper includes data and sections from author's dissertation submitted to the UCL Institute of Education.

\section{References}

Bakošová, Z. (2016). Inclusion of children from the socially disadvantaged environment: the case study of Slovakia. Forum Scientiae Oeconomia, 4(2), 61-72.

Cascella, C. (2020). Intersectional effects of Socioeconomic status, phase and gender on Mathematics achievement. Educational Studies, 46(4), 476-496. https://doi.org/10.1080/030556 98.2019.1614432 
Čitáryová, E., \& Chrenko, T. (2011). Analysis of the educational structure of Slovak population in terms of income levels. Medzinárodný seminár: Kvantitatívne metódy v ekonómií.

Eagle, E. (1989). Socioeconomic Status, Family Structure, and Parental Involvement: The Correlates of Achievement. Paper presented at the Annual Meeting of the American Educational Research Association, San Francisco, CA, March 27-31.

Farkašová, E., \& Zimmermann, M. (2014). Žiaci zo sociálne znevýhodňujúceho prostredia. Available at: https://www.komposyt.sk/pre-odbornikov/specialno-pedagogicka-cinnost/preview-file/ 1-3-1-ziaci-zo-socialne-znevyhodnujuceho-prostredia-474.pdf

Friedman, E., Kriglerová, E. G., Kubánová, M., \& Slosiarik, M. (2009). Škola ako geto. Systematické nadmerné zastúpenie Rómov v špeciálnom vzdelávaní na Slovensku. Bratislava: Roma Education Fund.

Government Office of the Slovak Republic. (2020). História vlád SR. Available at: https://vlada.gov. sk//historia-vlad-sr/

Hair, N. L., Hanson, J. L., Wolfe, B. L., \& Pollak, S. D. (2015). Association of child poverty, brain development, and academic achievement. JAMA pediatrics, 169(9), 822-829. https://doi.org/10.1001/ jamapediatrics.2015.1475

Hawthorne, G. \& Elliott, P. (2005). Imputing cross-sectional missing data: comparison of common techniques. Australian and New Zealand Journal of Psychiatry, 39(7), 583-590. https:// doi.org/10.1080/j.1440-1614.2005.01630.x

Kovalčíková, I., \& Džuka, J. (2014). Konceptualizácia pojmu sociálne znevýhodňujúce prostredie. Pedagogika.sk, 5(1), 5-27.

Ministry of Education of the Slovak Republic. 2013. Dieta zo sociálne znevýhodneného prostredia. Available at: https://minedu.sk/data/att/6072.pdf

Paterson, L. (1991). Socio-economic status and educational attainment: a multi-dimensional and multi-level study. Evaluation \& Research in Education, 5(3), 97-121. https://doi.org/10.1080/ 09500799109533303

Rochovská, A. \& Rusnáková, J. (2018). Poverty, segregation and social exclusion of Roma communities in Slovakia. Bulletin of Geography, Socio-economic Series, (42), 195-212. https://doi. org/10.1515/bog-2018-0039

Willms, J. D. (2010). School Composition and Contextual Effects on Student Outcomes. Teachers College Record, 112(4), 1008-1034.

\section{Contact:}

Tomáš Lintner, MA

Department of Educational Sciences, Faculty of Arts, Masaryk University

Arna Nováka 1, 60200 Brno, Czech Republic

E-mail: tomas.lintner@mail.muni.cz

Tomáš Lintner is a PhD student at the Department of Educational Sciences at Masaryk University. In his research, he focuses on social network analysis, sociology of education, and communication in classroom. 